\title{
Purification and Characterization of Glucosyltransferases from Streptococcus mutans 6715
}

\author{
By TAKUSHI FURUTA, TOSHIHIKO KOGA, TOSIKI NISIZAWA, \\ NOBUO OKAHASHI AND SHIGEYUKI HAMADA* \\ Department of Dental Research, The National Institute of Health, Kamiosaki, Shinagawa-ku, \\ Tokyo, 141 Japan
}

(Received 9 July 1984 ; revised 29 August 1984)

\begin{abstract}
A water-soluble glucan-synthesizing glucosyltransferase (GTase-S) and a water-insoluble glucan-synthesizing glucosyltransferase (GTase-I) were purified from culture supernatant of Streptococcus mutans 6715 (serotype $g$ ) by ammonium sulphate precipitation, chromatofocusing on a Polybuffer exchanger PBE 94 column, and subsequent phenyl-Sepharose CL-4B or hydroxyapatite column chromatography. The GTase-S and GTase-I activities were purified 4019- and 4714-fold, respectively, and the molecular weights were calculated to be 160000 and 165000 , respectively. GTase-S had a $\mathrm{pH}$ optimum of $5 \cdot 0$, a $K_{\mathrm{m}}$ of $8.8 \mathrm{~mm}$ for sucrose in the presence of $20 \mu \mathrm{M}$-dextran T10, and an isoelectric point of $\mathrm{pH} 4 \cdot 3$. GTase-I had two $\mathrm{pH}$ optima of 5.0 and $7.0, K_{\mathrm{m}}$ values of $4.9 \mathrm{~mm}($ at pH 5.0$)$ and $7.0 \mathrm{mM}$ (at pH 7.0), and an isoelectric point of pH 4.9. Methylation analysis indicated that the water-soluble glucan produced by GTase-S was a highly branched 1,6- $\alpha$-linked D-glucan with 1,3-linked glucose residues, and that the waterinsoluble glucan synthesized by GTase-I was composed of 1,3- $\alpha$-linked glucose units.
\end{abstract}

\section{INTRODUCTION}

Streptococcus mutans has been strongly implicated as a causative organism of dental caries (Hamada \& Slade, 1980). This organism produces both water-soluble and water-insoluble glucans from sucrose by its constitutive enzymes, glucosyltransferases (GTase; EC 2.4 1 . 5). De novo synthesis of the water-insoluble glucan is involved in the firm attachment and accumulation of $S$. mutans cells on tooth surfaces. The glucan has a highly branched structure with 1,3- $\alpha$-linked and 1,6- $\alpha$-linked D-glucose residues (Hamada \& Slade, 1980).

Many purification procedures for $S$. mutans GTases have been proposed (Montville et al., 1978; Ciardi, 1983). However, most of the reported GTases were still not fully purified. They formed molecular aggregates, and were contaminated by impurities such as fructosyltransferase, dextranase, invertase and lipoteichoic acid. Recently, two GTase components were purified by the chromatofocusing method from culture supernatant of $S$. mutans of serotype $d$ (Koga et al., $1983 b$ ) and $c$ strains (Kuramitsu \& Wondrack, 1983). In this report we describe a simple and reproducible procedure, using the chromatofocusing method, for purification of GTases of $S$. mutans 6715 (serotype $g$ ). Some properties of purified GTases are also discussed.

\section{METHODS}

Materials. S. mutans 6715 (serotype $g$ ) was from the stock culture collection in the Department of Dental Research, the National Institute of Health, Tokyo, Japan. Polybuffer exchanger PBE 94, Polybuffer 74, phenylSepharose CL-4B, and dextran T10 were obtained from Pharmacia. Hydroxyapatite was purchased from Seikagaku Kogyo Co., Tokyo. [U-1+C]Sucrose $\left(4.67 \mathrm{Ci} \mathrm{mol}^{-1} ; 0.17 \mathrm{TBq} \mathrm{mol}^{-1}\right)$ was obtained from New England Nuclear. Brain Heart infusion broth was from Difco, and invertase (EC 3.2.1.26) was from Wako Pure Chemicals, Osaka, Japan. SDS-PAGE standard proteins were from Bio-Rad.

Abbreviations: GTase-S, soluble glucosyltransferase; GTase-I, insoluble glucosyltransferase. 
Enzyme assays. GTase activity was measured as described previously (Koga \& Inoue, 1981). Enzyme was allowed to react with $10 \mathrm{mM}-\left[\mathrm{U}^{-14} \mathrm{C}\right]$ sucrose $\left(0.4 \mathrm{Ci} \mathrm{mol}^{-1} ; 14.8 \mathrm{GBq} \mathrm{mol}^{-1}\right)$ and $20 \mu \mathrm{M}$-dextran T10 in $20 \mu 10 \cdot 1 \mathrm{M}-$ potassium phosphate buffer, $\mathrm{pH} 6.0$, containing $0.02 \%(\mathrm{w} / \mathrm{v})$ sodium azide. After incubation at $37^{\circ} \mathrm{C}$ for $1 \mathrm{~h}$, the reaction mixture was spotted on a filter paper square $(15 \times 15 \mathrm{~mm}$, no. 514 , Toyo Roshi, Tokyo). The squares were washed three times with methanol and dried. Radioactivity retained on the paper squares was measured by a scintillation spectrometer to quantify the total glucan synthesized. One unit of GTase activity was defined as the amount of enzyme that transformed $1 \mu \mathrm{mol}$ of sucrose to glucan per min under the conditions described above.

The release of reducing sugar and glucose, and the synthesis of water-insoluble glucan from sucrose by GTases were also estimated. The reaction mixture consisted of $30 \mathrm{~mm}$-sucrose with appropriate amounts of enzyme solution and dextran $\mathrm{T} 10\left(0,0.5\right.$ or $\left.10 \mathrm{mg} \mathrm{ml}^{-1}\right)$ in a total volume of $3 \mathrm{ml} 0.1 \mathrm{M}$-phosphate buffer, $\mathrm{pH} 6.0$, containing $0.02 \%(\mathrm{w} / \mathrm{v})$ sodium azide. After incubation at $37^{\circ} \mathrm{C}$ for $4 \mathrm{~h}$, the amounts of reducing sugar and glucose released from sucrose were measured by the method of Somogyi (1945) and the glucose oxidase method (Blood Sugar GOD Perid Test; Boehringer-Mannheim), respectively, with glucose as a standard. To determine the waterinsoluble glucan, the glucan formed in the reaction mixture was dispersed by sonic oscillation, and $A_{550}$ was measured with a double-beam spectrophotometer (Hamada \& Torii, 1980).

Culture conditions and preparation of culture supernatant. Brain heart infusion broth $(185 \mathrm{~g})$ was pretreated with invertase ( $2 \mathrm{~g}$ ) to avoid contamination of sucrose, and dialysed against distilled water. The volume of the dialysate was adjusted to 41 with distilled water. The medium was autoclaved at $120^{\circ} \mathrm{C}$ for $15 \mathrm{~min}$, and 11 filter-sterilized $1.5 \%(\mathrm{w} / \mathrm{v})$ glucose solution was added. S. mutans 6715 was grown in this medium at $37^{\circ} \mathrm{C}$ for $18 \mathrm{~h}$. The cell-free culture supernatant was collected by centrifugation at $10000 \mathrm{~g}$ for $20 \mathrm{~min}$ at $4{ }^{\circ} \mathrm{C}$.

Purification of GTases. This was done at $4{ }^{\circ} \mathrm{C}$ unless otherwise specified. (1) Ammonium sulphate precipitation. Crude GTase was precipitated from the culture supernatant by adding solid ammonium sulphate to $50 \%$ saturation. The precipitate was collected by centrifugation, dissolved in $25 \mathrm{~mm}$-piperidine/ $\mathrm{HCl}$ buffer, $\mathrm{pH} 5.5$, and dialysed against the buffer. Insoluble material was removed by centrifugation at $10000 \mathrm{~g}$ for $30 \mathrm{~min}$.

(2) Chromatofocusing column chromatography. This was done as described previously, with some modifications (Koga et al., 1983 $\mathrm{b}$ ). The crude GTase $(30 \mathrm{ml})$ was applied to a column $(1.5 \times 30 \mathrm{~cm})$ of Polybuffer exchanger PBE 94 equilibrated with $25 \mathrm{~mm}$-piperidine $/ \mathrm{HCl}$ buffer, $\mathrm{pH} 5.5$. The enzyme was first eluted with fivefold diluted Polybuffer $74(\mathrm{pH} 4 \cdot 1,300 \mathrm{ml}$ ), followed by elution with a linear gradient of $0 \cdot 1$ to $0 \cdot 4 \mathrm{M}-\mathrm{NaCl}$ $(300 \mathrm{ml})$. Fractions of $10 \mathrm{ml}$ were collected at a flow rate of $15 \mathrm{ml} \mathrm{h}^{-1}$. A water-insoluble glucan-synthesizing GTase (GTase-I) and a water-soluble glucan-synthesizing GTase (GTase-S) were eluted at $0 \cdot 15$ and $0 \cdot 31 \mathrm{M}-\mathrm{NaCl}$, respectively. Active fractions were pooled for each peak, concentrated by precipitation with $80 \%$ saturated ammonium sulphate, and dialysed against $10 \mathrm{mM}$-phosphate buffer, $\mathrm{pH} 6.8$.

(3) Hydroxyapatite column chromatography. The GTase-I fraction $(10 \mathrm{ml})$ separated by chromatofocusing column chromatography was applied to a column $(0.7 \times 8 \mathrm{~cm})$ of hydroxyapatite equilibrated with $10 \mathrm{mM}-$ phosphate buffer, pH 6.8. The column was washed with the buffer $(20 \mathrm{ml})$, and then the enzyme was eluted with a linear gradient of 10 to $500 \mathrm{~mm}$-phosphate buffer ( $\mathrm{pH} \mathrm{6.8,90} \mathrm{ml).} \mathrm{Fractions} \mathrm{of} 3 \mathrm{ml}$ were collected at a flow rate of $18.6 \mathrm{ml} \mathrm{h}^{-1}$ at $25^{\circ} \mathrm{C}$. Active fractions were pooled, concentrated with an Amicon CF- 25 membrane, and dialysed against $10 \mathrm{~mm}$-phosphate buffer, pH 6.8.

(4) Phenyl-Sepharose CL-4B column chromatography. The GTase-S fraction (10 ml) separated by chromatofocusing column chromatography was dialysed against $1 \mathrm{M}$-ammonium sulphate in $10 \mathrm{~mm}$-phosphate buffer, pH 6.8. The fraction was applied to a column $(1.5 \times 10 \mathrm{~cm})$ of phenyl-Sepharose CL-4B equilibrated with the same buffer. Proteins were eluted with a linear gradient of 1 to $0 \mathrm{M}$-ammonium sulphate in $10 \mathrm{~mm}$-phosphate buffer, pH $6.8(120 \mathrm{ml})$. Fractions of $3 \mathrm{ml}$ were collected at a flow rate of $36 \mathrm{ml} \mathrm{h}^{-1}$ at $25^{\circ} \mathrm{C}$. Active fractions were pooled, concentrated with an Amicon CF-25 membrane, and dialysed against 10 mM-phosphate buffer, pH 6.8.

$S D S-P A G E$. SDS-polyacrylamide slab gels were prepared as described by Laemmli (1970). Enzyme proteins $(20 \mu \mathrm{g})$ were heated at $100{ }^{\circ} \mathrm{C}$ for $5 \mathrm{~min}$ in $10 \mathrm{~mm}$-Tris/HCl buffer, $\mathrm{pH} 6.8$, containing $1 \%(\mathrm{w} / \mathrm{v}) \mathrm{SDS}, 1 \%(\mathrm{w} / \mathrm{v}) 2-$ mercaptoethanol and $20 \%(\mathrm{w} / \mathrm{v})$ glycerol. Electrophoresis was performed at $10 \mathrm{~mA}$ per gel at $4{ }^{\circ} \mathrm{C}$ for $16 \mathrm{~h}$ using a $7 \cdot 5 \%(w / v)$ resolving and a $3 \%(w / v)$ stacking gel $(14 \times 11 \times 0 \cdot 2 \mathrm{~cm})$ containing $0.1 \%$ SDS. Proteins were stained with Coomassie brilliant blue R-250. Ovalbumin (mol. wt 45000), bovine serum albumin (66200), phosphorylase B (92500), $\beta$-galactosidase (116250) and myosin (200000) were used as molecular weight standards.

Electrophoretic blotting. Enzyme proteins $(20 \mu \mathrm{g})$ were electrophoresed in SDS-polyacrylamide slab gels as described above, and transferred to a nitrocellulose sheet by the electrophoretic blotting technique (Towbin et al., 1979). After confirmation of the transfer of the proteins by staining of a portion of the sheet with Coomassie R250 , another portion was treated with IG-3E7 monoclonal antibody which reacted specifically with GTase-I (Furuta et al., 1983). The antibody bound to the immobilized replica proteins on the sheet was detected by solidphase immunoassay with horseradish peroxidase-conjugated rabbit anti-mouse immunoglobulin.

Analytical isoelectric focusing. Enzyme proteins $(20 \mu \mathrm{g})$ were subjected to isoelectric focusing on an LKB Ampholine polyacrylamide gel plate with a pH range of 3.5 to 9.5 and run in an LKB Multiphor electrophoresis chamber. After focusing at $300 \mathrm{~V}$ for $2 \mathrm{~h}$, the gel was incubated in $10 \mathrm{~mm}$-phosphate buffer, $\mathrm{pH} 6.0$, containing $5 \%$ 
(w/v) sucrose, $50 \mu \mathrm{M}$-dextran T10 and $0.02 \%(\mathrm{w} / \mathrm{v})$ sodium azide at $37^{\circ} \mathrm{C}$ for $24 \mathrm{~h}$. Glucans formed on the gel were stained by the periodic acid-Schiff base method (Russell, 1979; Zacharius et al., 1969).

Determination of $K_{\mathrm{m}}$ value. The reaction mixture $(20 \mu \mathrm{l})$ consisted of $\mathrm{McIlvain}$ (citrate/ $\mathrm{Na}_{2} \mathrm{HPO}_{4}$ ) buffer at the appropriate $\mathrm{pH}$, appropriate amount of enzymes, and 2 to $10 \mathrm{mM}-\left[\mathrm{U}-{ }^{14} \mathrm{C}\right]$ sucrose in the presence or absence of $20 \mu \mathrm{M}$-dextran T10. After incubation at $37^{\circ} \mathrm{C}$ for $30 \mathrm{~min}$, the total glucan synthesized was determined as described above. The $K_{\mathrm{m}}$ values were estimated by using the initial velocity obtained at various substrate concentrations by the method of Eadie and Hofstee.

Amino acid analysis. Enzyme proteins $(0 \cdot 2 \mathrm{mg})$ were hydrolysed in $6 \mathrm{M}-\mathrm{HCl}$, in vacuo, at $110^{\circ} \mathrm{C}$ for $24 \mathrm{~h}$, and then analysed by a Hitachi 835-50 amino acid analyser (Spackman et al., 1958). Tryptophan was determined after hydrolysis in $3 \mathrm{M}-2$-mercaptoethanesulphonic acid.

Methylation analysis. Enzyme samples ( $400 \mathrm{mU}$ ) were allowed to react with $30 \mathrm{~mm}$-sucrose in a total volume of $3 \mathrm{ml} 0.1 \mathrm{M}$-phosphate buffer, $\mathrm{pH} 6.0$, containing $0.02 \%(\mathrm{w} / \mathrm{v})$ sodium azide. After incubation at $37^{\circ} \mathrm{C}$ for $72 \mathrm{~h}$, the synthesized glucans were precipitated by the addition of 3 vols ethanol, and the resulting precipitates were collected by centrifugation. The glucans were washed three times with $75 \%(\mathrm{v} / \mathrm{v})$ ethanol, and the precipitates were lyophilized.

Glucans (1 mg) were methylated by the method of Hakomori (1964) with sodium methylsulphinyl methanide and methyl iodine in methyl sulphoxide, and analysed as alditol acetates in a gas chromatograph as described by Hisamatsu et al. (1980).

Protein determination. Protein was measured by the Lowry method, with bovine serum albumin as a standard. The protein content of column effluents was monitored at $280 \mathrm{~nm}$ with a double-beam spectrophotometer (Model UV-190; Shimadzu Works, Kyoto, Japan).

\section{RESULTS}

\section{Purification of GTases}

Crude GTase, prepared by ammonium sulphate precipitation from the cell free culture supernatant of $S$. mutans 6715, was applied on a column of Polybuffer PBE 94 equilibrated with $25 \mathrm{~mm}$-piperidine/ $\mathrm{HCl}$ buffer, $\mathrm{pH} 5.5$. Two active peaks were eluted by $\mathrm{NaCl}$, at $0.15 \mathrm{M}$ - and $0.31 \mathrm{M}-\mathrm{NaCl}$ (Fig. 1). The enzyme eluted at $0.15 \mathrm{M}-\mathrm{NaCl}$ (GTase-I) produced a water-insoluble glucan from sucrose, whereas the enzyme eluted at $0.31 \mathrm{M}-\mathrm{NaCl}$ (GTase-S) produced a watersoluble glucan.

The GTase-I fraction was further chromatographed on a hydroxyapatite column (Fig. 2). No GTase activity was found in the major protein peak eluted with $10 \mathrm{~mm}$-phosphate buffer. The enzyme was eluted with approximately $0 \cdot 1 \mathrm{M}$-potassium phosphate. Active fractions (fractions 15 to 22 ) were pooled, concentrated, and dialysed against 10 mM-phosphate buffer, pH 6.8.

The GTase-S fraction separated by the chromatofocusing method was applied to a column of phenyl-Sepharose CL-4B equilibrated with $1 \mathrm{M}$-ammonium sulphate in $10 \mathrm{~mm}$-phosphate

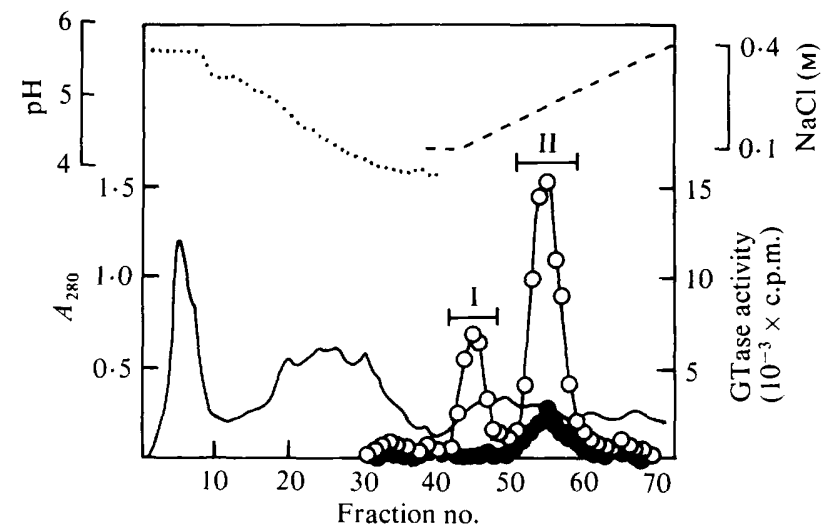

Fig. 1. Separation of GTase-I and GTase-S from the ammonium sulphate fraction of $S$. mutans 6715 extracellular glucosyltransferases by chromatofocusing on a Polybuffer exchanger PBE 94 column. Column dimension, $1.5 \times 30 \mathrm{~cm}$; flow rate, $15 \mathrm{ml} \mathrm{h}^{-1}$; volume per fraction, $10 \mathrm{ml}$. - Absorbance at $280 \mathrm{~nm}$. Glucosyltransferase was assayed with $10 \mathrm{mM}-\left[\mathrm{U}^{-14} \mathrm{C}\right]$ sucrose in the presence $(\mathrm{O})$ or absence (O) of $20 \mu \mathrm{M}$-dextran T10. I, GTase-I; II, GTase-S. $\cdots$, pH gradient; ---, $\mathrm{NaCl}$ gradient. 


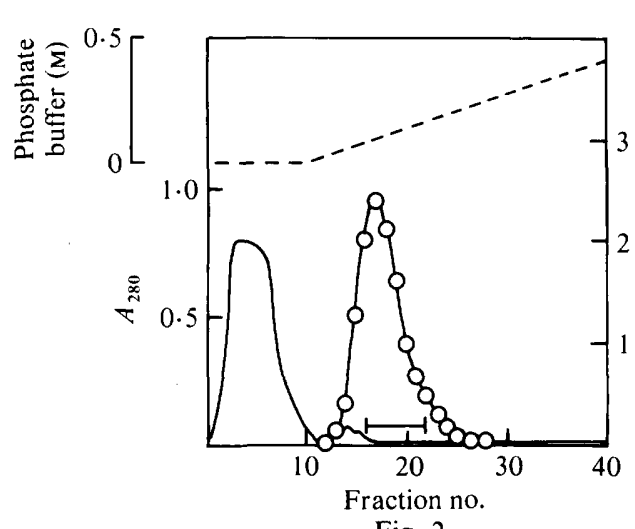

Fig. 2

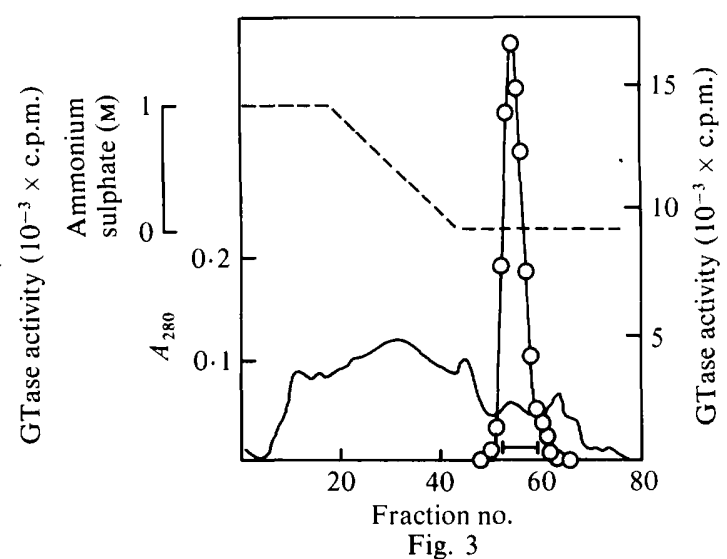

Fig. 3

Fig. 2. Purification of GTase-I by hydroxyapatite column chromatography. Column dimension, $0.7 \times 8 \mathrm{~cm}$; flow rate, $19 \mathrm{ml} \mathrm{h}^{-1}$; volume per fraction, $3 \mathrm{ml}$. - Absorbance at $280 \mathrm{~nm}$. Glucosyltransferase $(O)$ was assayed with $10 \mathrm{mM}-\left[\mathrm{U}-{ }^{14} \mathrm{C}\right]$ sucrose in the presence of $20 \mu \mathrm{M}$-dextran T10. --- , Phosphate buffer gradient.

Fig. 3. Purification of GTase-S by phenyl-Sepharose CL-4B column chromatography. Column dimension, $1.5 \times 10 \mathrm{~cm}$; flow rate, $36 \mathrm{ml} \mathrm{h}^{-1}$; volume per fraction, $3 \mathrm{ml}$. - Absorbance at $280 \mathrm{~nm}$. Glucosyltransferase $(O)$ was assayed with $10 \mathrm{~mm}-\left[\mathrm{U}^{-14} \mathrm{C}\right]$ sucrose in the presence of $20 \mu \mathrm{M}$-dextran T10. --- Ammonium sulphate gradient.

Table 1. Purification of glucosyltransferase from S. mutans 6715

\section{Step}

1. Culture supernatant

2. $50 \%$ Ammonium sulphate

3. Chromatofocusing GTase-S GTase-I

4. Phenyl-Sepharose CL-4B GTase-S

5. Hydroxyapatite GTase-I

$\begin{array}{ccccc}\begin{array}{c}\text { Total } \\ \text { protein } \\ (\mathrm{mg})\end{array} & \begin{array}{c}\text { Total } \\ \text { activity } \\ (\mathrm{U})\end{array} & \begin{array}{c}\text { Specific } \\ \text { activity } \\ \left(\mathrm{U} \mathrm{mg}^{-1}\right)\end{array} & \begin{array}{c}\text { Recovery } \\ (\%)\end{array} & \begin{array}{c}\text { Purification* } \\ \text { (fold) }\end{array} \\ 42400 & 23.9 & 0.00056 & 100 & 1 \\ 491 & 21.0 & 0.0427 & 87.9 & 76 \\ & & & & \\ 27.5 & 6.09 & 0.221 & 25.5 & 395 \\ 25.2 & 1.54 & 0.611 & 6.44 & 109 \\ 1.22 & 2.75 & 2.25 & 11.5 & 4019 \\ 0.24 & 0.63 & 2.63 & 2.64 & 4714\end{array}$

* Measurement of protein concentration in the crude broths usually results in a gross overestimate because of the presence of a number of interfering small molecules. Consequently the true purification values are probably smaller than those listed.

buffer, pH 6.8 (Fig. 3). No GTase activity was found in non-adsorbed proteins washed from the resin with starting buffer, or in bound proteins eluted by lowering the ammonium sulphate concentration ( 1 to $0 \mathrm{M})$. The enzyme was eluted by subsequent irrigation with $10 \mathrm{~mm}$-phosphate buffer, $\mathrm{pH} 6 \cdot 8$. Active fractions (fractions 52 to 58 ) were pooled and concentrated.

A typical enzyme purification is summarized in Table 1. Purification of GTase-I was 4714fold with an overall yield of $2 \cdot 6 \%$, and that of GTase-S was 4019 -fold with an overall yield of $11.5 \%$.

\section{Properties of purified GTases}

SDS-PAGE showed homogeneity of the purified GTase preparations (Fig. 4a). The molecular weights of purified GTase-I and GTase-S were estimated to be $165000 \pm 3000$ and $160000 \pm 3000$ (mean \pm SD from five independent experiments), respectively.

Analytical isoelectric focusing of purified GTases revealed that the pI values of GTase-I and GTase-S were $4.9 \pm 0.2$ and $4 \cdot 3 \pm 0 \cdot 1$ (mean \pm SD from three separate experiments), respectively. 
$10^{-3} \times$

Mol. wt 2 3 1 2

(a)

(b)

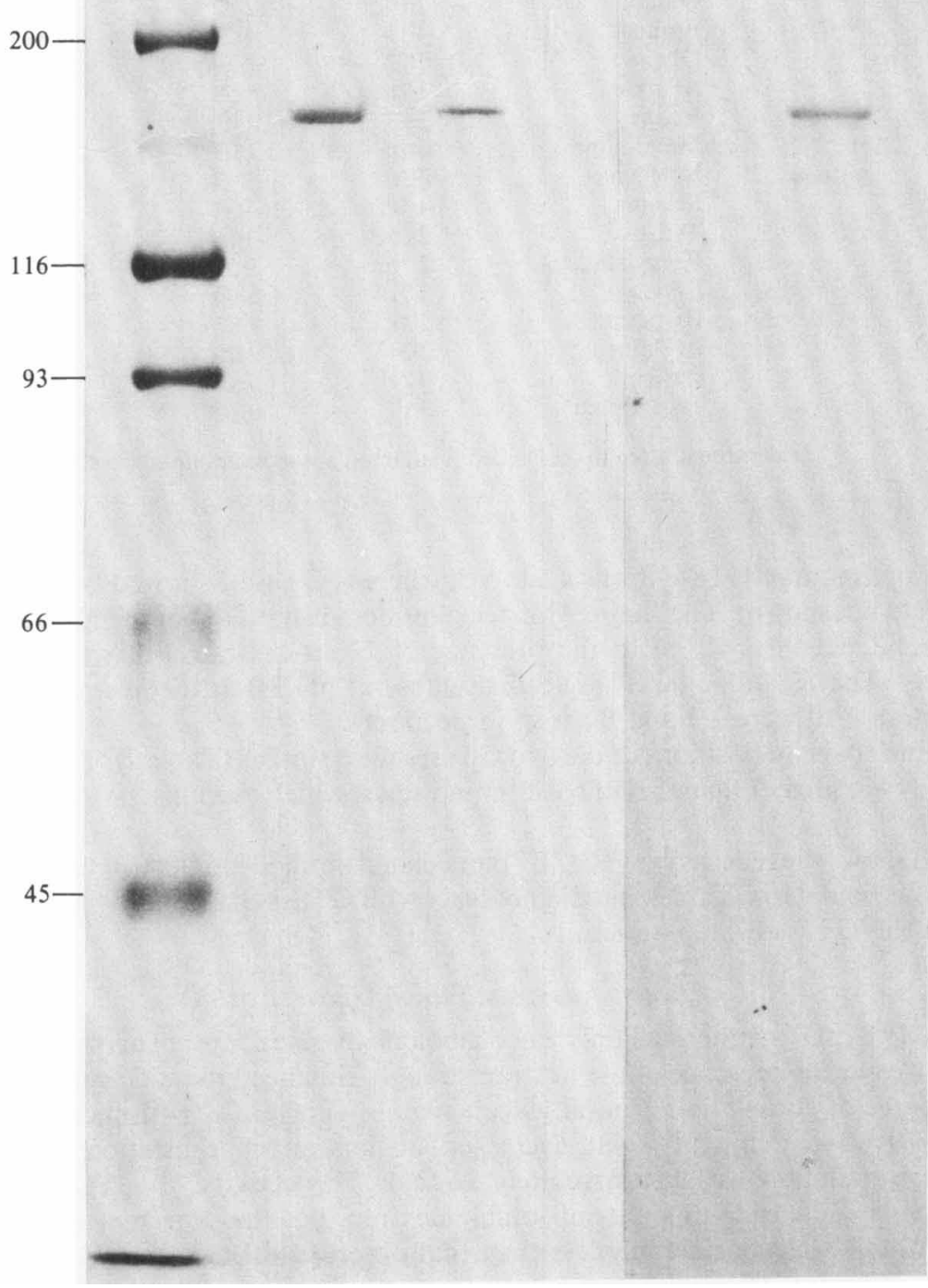

Fig. 4. SDS-PAGE and electrophoretic blotting of purified GTase-I and GTase-S. (a) SDSpolyacrylamide gel electrophoretic pattern. Electrophoresis was performed with $7.5 \%$ acrylamide, containing $20 \mu \mathrm{g}$ of each enzyme. The gel was stained with Coomassie brilliant blue. Molecular weight markers used were ovalbumin (mol. wt. 45000), bovine serum albumin (66200), phosphorylase B (92500), $\beta$-galactosidase (116250) and myosin (200000). (b) IG-3G7 monoclonal antibody bound to an immobilized antigen on a nitrocellulose sheet transferred by an electrophoretic blotting procedure. The antibody was detected by solid-phase immunoassay with horseradish peroxidase-conjugated rabbit anti-mouse immunoglobulin. (a) Lane 1, molecular weight markers; lane 2, GTase-S; lane 3, GTase-I. (b) Lane 1, GTase-S; lane 2, GTase-I. 
Table 2. Amino acid compositions of purified glucosyltransferases from S. mutans 6715

\begin{tabular}{|c|c|c|}
\hline \multirow[b]{2}{*}{ Amino acid } & \multicolumn{2}{|c|}{ Composition $(\mathrm{mol} \%)$} \\
\hline & GTase-I & GTase-S \\
\hline Aspartic acid & $9 \cdot 02$ & $10 \cdot 05$ \\
\hline Threonine & $5 \cdot 39$ & $5 \cdot 83$ \\
\hline Serine & $14 \cdot 73$ & $12 \cdot 47$ \\
\hline Glutamic acid & $12 \cdot 10$ & $12 \cdot 72$ \\
\hline Proline & $4 \cdot 11$ & 4.73 \\
\hline Glycine & $15 \cdot 22$ & $13 \cdot 59$ \\
\hline Alanine & $8 \cdot 76$ & $11 \cdot 59$ \\
\hline Valine & $3 \cdot 83$ & $4 \cdot 01$ \\
\hline Methionine & 0.90 & 1.01 \\
\hline Isoleucine & $2 \cdot 30$ & 2.67 \\
\hline Leucine & $4 \cdot 42$ & $4 \cdot 34$ \\
\hline Tyrosine & 2.66 & $3 \cdot 16$ \\
\hline Phenylalanine & $2 \cdot 76$ & $2 \cdot 54$ \\
\hline Lysine & $8 \cdot 71$ & 6.99 \\
\hline Histidine & $2 \cdot 41$ & 1.87 \\
\hline Arginine & $2 \cdot 34$ & $2 \cdot 05$ \\
\hline Cysteine & $0 \cdot 23$ & 0.32 \\
\hline Tryptophan* & $0 \cdot 19$ & $0 \cdot 10$ \\
\hline
\end{tabular}

The $\mathrm{pH}$ optimum of GTase-S was 4.5 to $5 \cdot 5$, whereas GTase-I showed two pH optima of 5.0 and 7.0 (data not shown). The Eadie-Hofstee plots demonstrated that the $K_{\mathrm{m}}$ values of GTase-I for sucrose at $\mathrm{pH} 5.0$ and 7.0 in the presence of $20 \mu \mathrm{M}$-dextran T10 were 4.9 and $7.0 \mathrm{mM}$, respectively. The $K_{\mathrm{m}}$ value of GTase-S for sucrose at $\mathrm{pH} \mathrm{5.0}$ in the absence and presence of $20 \mu \mathrm{M}$-dextran T10 were $2 \cdot 2$ and $8.8 \mathrm{mM}$, respectively.

The amino acid compositions of the two GTases were similar (Table 2). The content of acidic amino acids was greater than that of basic amino acids, which explains the low $\mathrm{pI}$ values of these enzymes.

Fig. 4(b) shows the reactivity of IG-3E7 monoclonal antibody to the two GTases. The IG-3E7 antibody was bound to GTase-I, but did not react with GTase-S, indicating that no GTase-I was present in the GTase-S preparation.

\section{Effects of dextran T10 on GTase activities}

GTase-I $(9.8 \mathrm{mU})$ synthesized only trace amounts of glucan from sucrose in the absence of dextran T10, but the presence of the dextran strongly enhanced the total glucan synthesis (Fig. 5). The degree of stimulation of total glucan synthesis increased with increasing amounts of dextran T10 up to $5 \mathrm{mg} \mathrm{ml}^{-1}$ but decreased at dextran concentration above $5 \mathrm{mg} \mathrm{ml}^{-1}$; maximum stimulation was approximately 16-fold. The activity of GTase-S $(9.5 \mathrm{mU})$ also increased with increasing amounts of soluble dextran, but the degree of stimulation of total glucan synthesis was considerably less than that observed for GTase-I.

GTase-I $\left(40 \mathrm{mU} \mathrm{ml}^{-1}\right)$ synthesized only trace amounts of water-insoluble glucan in the absence of dextran T10, but the synthesis of such glucan was significantly stimulated by the addition of dextran $\mathrm{T} 10$ at a concentration of $0.5 \mathrm{mg} \mathrm{m}^{-1}$ (Table 3). No water-insoluble glucan was synthesized by GTase-S $\left(76 \mathrm{mU} \mathrm{ml}^{-1}\right)$ in the absence or presence of dextran T10.

Both enzymes released free glucose from sucrose (Table 3); the amount released was smaller in the presence of dextran T10. No detectable fructosyltransferase activity was demonstrated, as judged by the incorporation of radioactivity into polysaccharide from 1-O-( $\alpha$-D-glucopyranosyl)$\beta$-D- $\left[\mathrm{U}-{ }^{14} \mathrm{C}\right]$ fructofuranoside (sucrose labelled in the fructosyl moiety). Furthermore, no dextranase activity was present in these GTases, which was demonstrated by the fact that these enzymes did not release reducing sugars from dextran T2000 after $1 \mathrm{~h}$ incubation in $0.1 \mathrm{M}$ phosphate buffer, $\mathrm{pH} 6.0$, at $37^{\circ} \mathrm{C}$. 


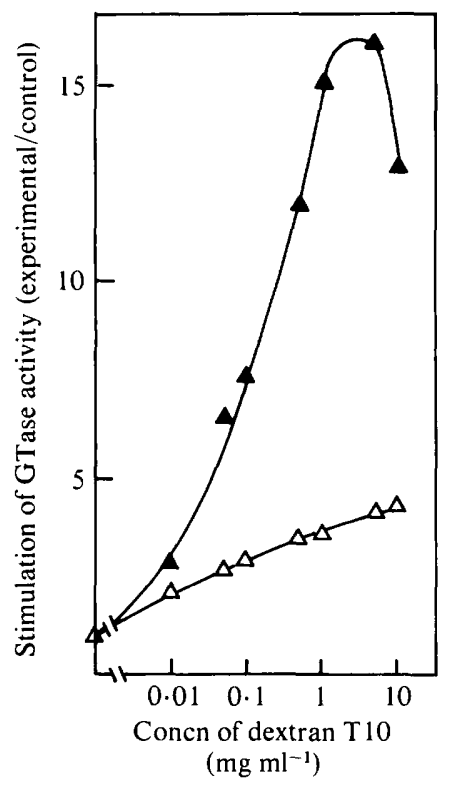

Fig. 5. Effect of dextran T10 on activity of GTase-I and GTase-S. Glucosyltransferase (10 mU) was allowed to react with $10 \mathrm{~mm}-\left[\mathrm{U}^{-14} \mathrm{C}\right]$ sucrose and 0 to $10 \mathrm{mg} \mathrm{ml}^{-1}$ dextran T10 in $20 \mu \mathrm{l} 0 \cdot 1 \mathrm{M}$-phosphate buffer ( $\mathrm{pH}$ 6.0). Activity is presented as the ratio to control activity (no added dextran T10). $\triangle$, GTase-I. $\triangle$, GTase-S.

Table 3. Effects of dextran T10 on glucosyltransferase activities of S. mutans 6715

$\begin{array}{ccccc}\text { Dextran T10 } & \overbrace{\text { Glucose }} & \begin{array}{c}\text { Reducing sugar } \\ \left(\mu \mathrm{mol} \mathrm{m}^{-1} \mathrm{~min}^{-1}\right)\end{array} & \begin{array}{c}\text { Sugar release } \\ \text { Insoluble glucan } \\ \text { synthesis }\left(A_{550}\right)^{*}\end{array} \\ \text { GTase-I } & 10 & 13 & 93 & 0.004 \\ \text { GTase-S } & 0 \cdot 5 & 17 & 134 & 0.360 \\ & 0 & 19 & 103 & 0.004 \\ & 10 & 3 & 253 & 0.003 \\ & 0 \cdot 5 & 5 & 180 & 0.003 \\ & 0 & 7 & 29 & 0.003\end{array}$

\section{Linkage analysis of glucans synthesized by GTases}

It was shown by methylation analysis of glucans synthesized after $72 \mathrm{~h}$ by purified GTases in the absence of dextran T10 that glucan synthesized by GTase-I gave $92 \%$ 2,4,6-tri- $O$-methyl-Dglucose, which indicates that the glucan was a 1,3- $\alpha$-linked D-glucan with little branching. Water-soluble glucan synthesized by GTase-S gave $36 \mathrm{~mol} \% 2,3,4,6$-tetra- $O$-methyl-D-glucose, $47 \mathrm{~mol} \%$ 2,3,4-tri- $O$-methyl-D-glucose and $13 \mathrm{~mol} \%$ 2,4-di- $O$-methyl-D-glucose, indicating that the product of GTase-S consisted of a low molecular weight highly branched 1,6 - $\alpha$-linked Dglucan with 1,3-linked glucose residues.

\section{DISCUSSION}

In this study, GTases of $S$. mutans 6715 were resolved into two fractions by chromatofocusing. One fraction (GTase-I) synthesized water-insoluble glucan from sucrose, and the other (GTaseS) synthesized water-soluble glucan. It should be noted that after using a $\mathrm{pH}$ gradient as in orthodox chromatofocusing these GTases were eluted by an ionic strength gradient. However, 
no such separation of these GTases could be obtained by a simple ion exchange chromatography on the PBE column. GTase-I and GTase-S were purified to homogeneity by hydroxyapatite chromatography and by phenyl-Sepharose CL-4B chromatography, respectively.

The purified GTase-I had a molecular weight of $165000 \pm 3000$, and $\mathrm{pH}$ optima at 5.0 and 7.0. Recently, Fukui et al. (1982) purified a similar GTase-I from culture fluid of S. mutans 671515 by column chromatography on Toyopearl HW-60 and subsequently on hydroxyapatite. This purified enzyme had a molecular weight of 180000 , and pH optima at $5 \cdot 8$ and $7 \cdot 3$. However, the $K_{\mathrm{m}}$ values of their enzyme (1.4 mM at pH 5.8 and $3.3 \mathrm{~mm}$ at $\left.\mathrm{pH} 7.3\right)$ differ from those of GTase-I purified in the present study $(4.9 \mathrm{~mm}$ at $\mathrm{pH} 5.0$ and $7.0 \mathrm{~mm}$ at $\mathrm{pH} 7.0)$. This difference in the $K_{\mathrm{m}}$ value may be due to the differences in the enzyme assay method or the purity of the enzyme.

The molecular weight of the purified GTase-S was $160000 \pm 3000$ (Fig. 4), and the pI value was $4 \cdot 3 \pm 0 \cdot 1$. Shimamura et al. (1982) purified a similar enzyme from the culture supernatant of $S$. mutans 6715 , with a molecular weight of $149000 \pm 5000$, and a pI of $4 \cdot 1$. Further, the optimum pH in the presence of dextran T10 of their GTase-S are the same as those of our GTase-S.

The activity of GTase-I and GTase-S purified from the culture supernatant of S. mutans 6715 in this study was increased up to 16- and 5-fold, respectively, by the addition of dextran T10 to the enzyme assay. Dextran stimulation of $S$. mutans GTase-I activity has been observed by several investigators (Germaine et al., 1977; Hare et al., 1978; Fukui et al., 1982; Shimamura et al., 1982; Koga et al., 1983a). McCabe \& Smith (1977) reported that GTase-S from $S$. mutans 6715 is also stimulated by the addition of exogenous soluble dextran. In contrast, it has been shown that a GTase-S unaffected by an exogenous dextran is secreted by $S$. mutans OMZ 176 (Koga et al., 1983b) and 6715 (Shimamura et al., 1983) in medium supplemented with Tween 80. We found no such dextran-independent GTase-S in this study. Perhaps some of surfactants such as Tween 80 stimulate the production of dextran-independent GTase-S.

Luzio \& Mayer (1983) observed that GTase purified from the culture fluids of $S$. sanguis ATCC 10558 catalyses the hydrolysis of sucrose to glucose and fructose, and that the formation of glucan competes with the hydrolysis of sucrose. The GTases of $S$. mutans 6715 also could release glucose from sucrose, and the degree of release of glucose in the absence of dextran T10 was higher than that in its presence. The release of glucose from sucrose would occur if fructosyltransferase, dextranase and invertase were present. However, these enzymes were not detected. Moreover, the GTases purified in this study showed a single band with Coomassie brilliant blue on SDS-PAGE. These results indicate that the GTase itself possesses a hydrolytic activity and the release of glucose is due to transfer of glucosyl moieties to water.

Unlike crude GTase, GTase-I or GTase-S alone did not yield a turbid suspension from sucrose. Koga et al. (1983a) isolated a dextran-dependent GTase-I and a dextran-independent GTase-S from the culture supernatant of $S$. mutans OMZ 176, and indicated that the combined incubation of GTase-I and GTase-S is required to produce adherent water-insoluble glucan from sucrose. Further investigation will be needed to clarify whether or not water-soluble glucan produced by the GTase-S purified in the present study acts as an intrinsic acceptor for the glucan synthesis by the GTase-I.

In addition, the very low yields of GTases isolated is a common problem with reported purifications of these enzymes and has led to the worry that, against the background of multiple forms of GTases, the isolated species may not be very representative of the total (Ciardi, 1983). Therefore, presence of other species of GTase should also be investigated.

\footnotetext{
We are grateful to Dr Yoshinori Kuboki, Dental Clinical Laboratory and Department of Biochemistry, School of Dentistry, Tokyo Medical and Dental University, for performing the amino acid analyses, and Dr Tsuyoshi Yakushiji, Department of Preventive Dentistry, Kagoshima University Dental School, for performing the methylation analyses. We also thank Dr Floyd C. McIntire, Department of Oral Biology, School of Dentistry, University of Colorado Health Sciences Center, for his critical review of the manuscript and correction of the English.
} 


\section{REFERENCES}

Ciardi, J. E. (1983). Purification and properties of glucosyltransferases of Streptococcus mutans: a review. In Glucosyltransferases, Glucans, Sucrose and Dental Caries, pp. 51-64. Edited by R. J. Doyle \& J. E. Ciardi. Washington, DC: IRL Press.

Fukui, K., Moriyama, T., Miyake, T., Mizutani, K. \& TANAKA, O. (1982). Purification and properties of glucosyltransferase responsible for water-insoluble glucan synthesis from Streptococcus mutans. Infection and Immunity 37, 1-9.

Furuta, T., Nisizawa, T., Chiba, J. \& Hamada, S. (1983). Production of monoclonal antibody against a glucosyltransferase of Streptococcus mutans 6715. Infection and Immunity 41, 872-875.

Germaine, G. R., Harlander, S. K., Leung, W. L. S. \& SCHACHTEle, C. F. (1977). Streptococcus mutans dextransucrase: functioning of primer dextran and endogenous dextranase in water-soluble and waterinsoluble glucan synthesis. Infection and Immunity 16, 637-648.

HAKOMORI, S. (1964). A rapid permethylation of glycolipid and polysaccharide catalyzed by methylsulfinyl carbanion in dimethyl sulfoxide. Journal of Biochemistry 55, 205-208.

Hamada, S. \& Slade, H. D. (1980). Biology, immunology, and cariogenicity of Streptococcus mutans. Microbiological Review's 44, 311-384.

HaMada, S. \& TORII, M. (1980). Interaction of glucosyltransferase from Streptococcus mutans with various glucans. Journal of General Microbiology 116 , $51-59$.

Hare, M. D., Svensson, S. \& Walker, G. J. (1978). Characterization of the extracellular, water-insoluble $\alpha$-D-glucans of oral streptococci by methylation analysis, and by enzymic synthesis and degradation. Carbohydrate Research 66, 245-264.

Hisamatsu, M., Abe, J., Amemura, A. \& Harada, T. (1980). Structural elucidation of succinoglycan and related polysaccharides from Agrobacterium and Rhizobium by fragmentation with two special $\beta$-Dglucanases and methylation analysis. Agricultural and Biological Chemistry 44, 1049-1055.

KOGA, T. \& InOUE, M. (1981). Inactivation of Dglucosyltransferases from oral Streptococcus mutans and Streptococcus sanguis by photochemical oxidation. Carbohydrate Research 93, 125-133.

Koga, T., Sato, S., Inoue, M., Takeuchi, K., Furuta, T.\& Hamada, S. (1983a). Role of primers in glucan synthesis by glucosyltransferases from Streptococcus mutans strain OMZ176. Journal of General Microbiology 129, 751-754.
Koga, T., Sato, S., Yakushiji, T. \& Inoue, M. $(1983 b)$. Separation of insoluble and soluble glucansynthesizing glucosyltransferases of Streptococcus mutans OMZ176 (serotype d). FEMS Microbiology Letters 16, 127-130.

KuRamitsu, H. \& Wondrack, L. (1983). Insoluble glucan synthesis by Streptococcus mutans serotype $c$ strains. Infection and Immunity 42, 763-770.

LAEMMLI, U. K. (1970). Cleavage of structutal proteins during the assembly of the head of bacteriophage T4. Nature, London, 227, 680-685.

LuZio, G. A. \& MAYER, R. M. (1983). The hydrolysis of sucrose by dextransucrase. Carbohydrate Research 111, 311-318

MCCABE, M. M. \& Smith, E. E. (1977). Specific method for the purification of Streptococcus mutans dextransucrase. Infection and Immunity 16, 760-765.

Montville, T. J., Cooney, C. L. \& Sinskey, A. J. (1978). Streptococcus mutans dextransucrase: a review. Adrances in Applied Microbiology 24, 55-84.

RusSELL, R. R. B. (1979). Glycosyltransferases of Streptococcus mutans strain Ingbritt. Microbios 23, 135-146.

Shimamura, A., Tsumori, H. \& Mukasa, H. (1982). Purification and properties of Streptococcus mutans extracellular glucosyltransferase. Biochimica et biophysica acta 702, 72-80.

Shimamura, A., Tsumori, H. \& Mukasa, H. (1983). Three kinds of extracellular glucosyltransferases from Streptococcus mutans $6715 \mathrm{~S}$ (serotype $\mathrm{g}$ ). FEBS Letters 157, 79-84.

Somogyi, M. (1945). A new reagent for the determination of sugars. Journal of Biological Chemistry 160 , 61-68.

Spackman, D. H., Stein, W. H. \& Moore, S. (1958). Automatic recording apparatus for use in the chromatography of amino acids. Analytical Chemistry 30, 1190-1206.

Towbin, H., Staehelin, T. \& Gordon, J. (1979). Electrophoretic transfer of proteins from polyacrylamide gels to nitrocellulose sheets: procedure and some applications. Proceedings of the National Academy of Sciences of the United States of America 76, $4350-4354$.

Zacharius, R. M., Zell, T. E., Morrison, J. H. \& WooDlock, J. J. (1969). Glycoprotein staining following electrophoresis on acrylamide gels. Analytical Biochemistry 30, 148-152. 